\title{
Geostatistical Assessments for Characteristics of Soils around Naip Dam
}

\author{
Hüseyin Sarı*
}

Department of Soil Science and Plant Nutrition, Faculty of Agriculture, Tekirdağ Namık Kemal University, 59030 Tekirdağ, Turkey

\begin{abstract}
Investigation and mapping spatial variations (distance-dependent variations) in soil characteristics with the aid of geostatistical methods will bring about significant savings for labor, time and cost in agricultural practices. From this point forth, this study was conducted around Naipköy dam to determine spatial distribution of physical and chemical soil characteristics. Soil samples were taken from both sides of Tekirdağ Ganos Mountain (the side towards Naip plain and the side towards Marmora Sea). The research site was divided into 1000 × $2000 \mathrm{~m}$ grids and disturbed samples were taken from 0-30 cm soil profile of 24 points. Soil samples were subjected to texture, organic matter, $\mathrm{pH}, \mathrm{EC}$, calcium, magnesium, potassium and phosphorus analyses. Analyses revealed that the sections towards Naip plain had quite high clay and silt contents because of clayey deposition over these sections. These samples also had high calcium and thusly $\mathrm{pH}$ values because of lime layers of these sections. Soil properties were mapped in ArcGIS/ArcMAP 10.6 software with the aid of Inverse Distance Weighting (IDW) method. The maps generated facilitated assessments made for the relationships between land use and physico-chemical soil characteristics. Statistical analyses revealed the least coefficient of variation $(8.44 \%)$ for $\mathrm{pH}$ and the greatest coefficient of variation $(73.51 \%)$ for phosphorus.
\end{abstract}

Key Words: Geostatistics, Naip, GIS, Soil, Tekirdag, IDW

\section{Introduction}

It is impossible to measure soil characteristics in every single point of large areas. Therefore, representative samples are taken from such fields and soil characteristics of these samples are linked to entire field. Since some fields have quite heterogenous structures, there may be great variations among the soil samples. In such cases, classical statistics have quite narrow confidence limits. It is assumed that selected sampling points were independent of each other and sample mean best represented the population mean in classical statistics. It is normal to have quite similar sampling points in themselves when the sampling points were close to each other. Such similarities are function of the distance and thus should not be considered independent of the distance. Therefore, levels of spatial variations (spatial dependency) in investigated parameters should be determined. Geostatistical methods are successfully employed to determine such spatial dependency (Öztas 1995).

It is quite significant to determine distance-dependent variations in soil physical and chemical characteristics for investigation and mapping of soil characteristics and developing proper management methods accordingly (Denton et al. 2017).

In spatial analyses, two similar stages are applied for regression analysis and geostatistical analysis. Initially, the models defining spatial dependencies between investigated soil properties and sampling points are determined. Then, interpolation methods are used to estimate the values of non-sampled points with the aid of the values of sampled points and spatial distribution maps are generated for investigated soil characteristics. In these two stages, Moran's I index can be used for spatial dependence, and spatial regression method can be used for interpolations (Anselin 2002, 2009, Anselin et al. 2012).

Several researchers employed highly reliable geostatistical methods to identify the relationships between sampling distances and investigated parameters and to model distance-dependent variations in such parameters (Turgut and Oztas 2012, Goovaerts 1998, Webster and Oliver 2007, Erdem et al. 2012, Günal et 
al. 2012, Glendell et al. 2014, Sabeti et al. 2017, Cao et al. 2017, Denton et al. 2017, Vasu et al. 2017, Başbozkurt et al. 2013).

\section{Material and Method \\ Material}

The research site, Naip plain is located within the provincial boundaries of Tekirdağ province in Northwest of Turkey. The site is positioned at northeast of Ganos Mountain and lower sections of Ana stream passing through the plain and flowing into Marmora Sea (Özşahin et al. 2018, Özşahin 2015). The research site covers majority of the lands of Uçmakdere, Naipköy, Çanakçı, Işıklar, Oruçbeyli, Işıklar, Avşar and Yazır districts of Tekirdağ province. The site includes northeast section of Ganos Mountain and samples were taken from both sides of the mountain. Northern skirts of the mountain include Naip plain and southern sections of the mountain extend till Marmora Sea. Maps of the research site are presented in Fig. 1.a,b,c.

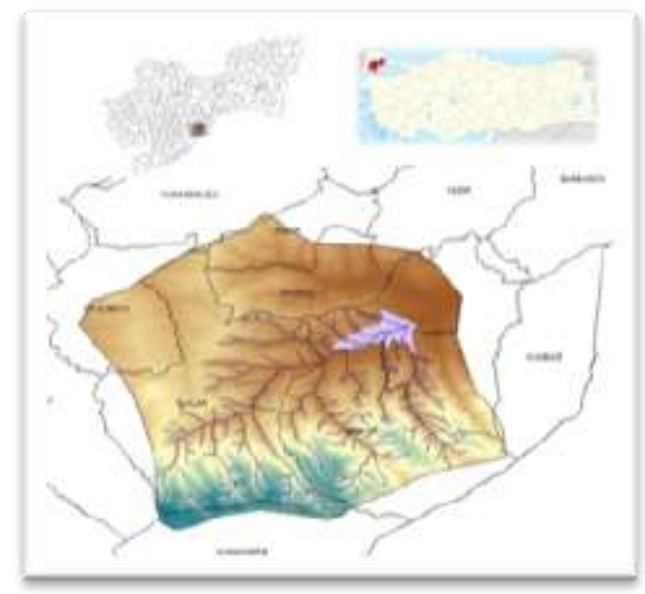

Fig.1.a.

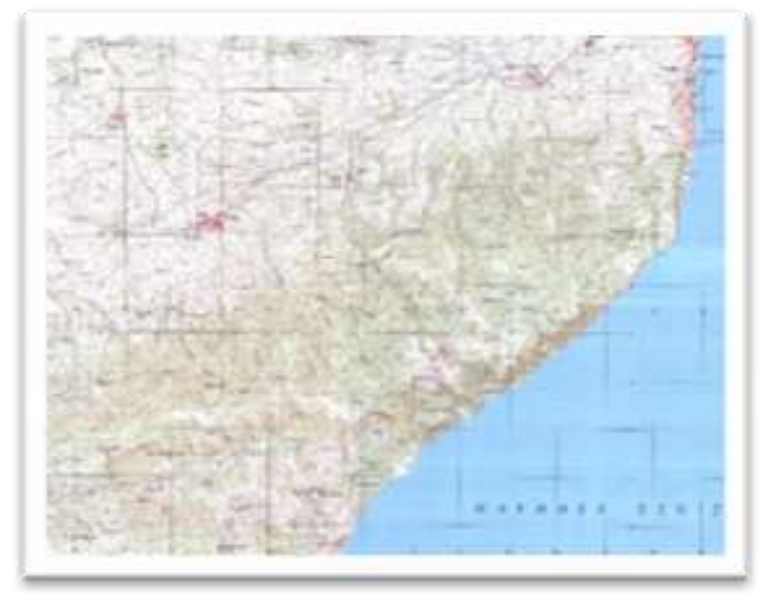

Fig.1.b.

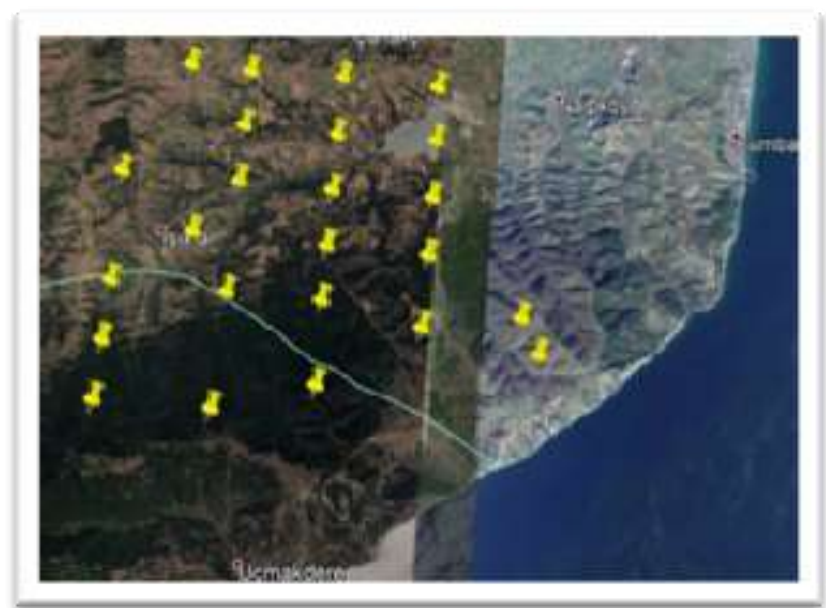

Fig.1.c.

Fig. 1. a,b,c. Topographical map of the research site and satellite image of sampling points

\section{Method}

The research site, Northeast side of Ganos Mountain, covers about $60.000 .000 \mathrm{~m}^{2}$ area. For sampling points, the site was divided into $2000 \mathrm{~m} \times 1000 \mathrm{~m}$ grids and samples were tried to be taken from the mid-section of each grid. Since the site has a quite rough topography, samples were not able to be taken from the midsections of some grids. Soil samples were taken from $0-30 \mathrm{~cm}$ soil profile of 24 points and brought to laboratory for analyses. Soil reaction $(\mathrm{pH})$ was determined in 1:2,5 soil-water suspension with a glasselectrode pH meter (Jackson 1958), EC was determined in 1:2,5 soil-water suspension with Wheatstone Bridge conductivity device (Richards 1954); soil texture (grain size distribution) was determined in accordance with Bouyoucos hydrometer method (Bouyoucos 1953) and texture triangle was used to name the texture classes (Anonymous 1993). Organic matter (\%) was determined with the aid of Smith-Weldon Method and Organic C method (Sağlam 2008). Ca, Mg and K contents were determined with the aid of 
Ammonium Acetate method and P contents were determined with Sodium bicarbonate method (Sağlam 2008).

Spatial distribution maps of all parameters were generated in ArcMap 10.6 software by using Inverse Distance Weighting (IDW) method (Anonymous 2009).

\section{Results}

Entire analysis results of the research site and coordinates of sampling points are provided in Table 1.

Table 1. Coordinates of sampling points and analysis results

\begin{tabular}{|c|c|c|c|c|c|c|c|c|c|c|c|c|c|}
\hline & Latitude & Longitude & $\begin{array}{c}\text { Sand } \\
\%\end{array}$ & Silt \% & $\begin{array}{c}\text { Clay } \\
\%\end{array}$ & $\begin{array}{c}\text { Teksture } \\
\text { Classification }\end{array}$ & ph & $\mathrm{EC}$ & $\begin{array}{c}\% \\
\text { OM }\end{array}$ & Magnesium & Calcium & Potassium & Phospor \\
\hline N1 & 27,414608 & 40,837685 & 28,59 & 38,68 & 32,73 & CL & 5,84 & 145 & 3,59 & 330,33 & 1745,26 & 271,88 & 18,63 \\
\hline $\mathrm{N} 2$ & 27,418579 & 40,832470 & 44,68 & 30,64 & 24,68 & $\mathrm{~L}$ & 7,10 & 232 & 0,72 & 591,61 & 3179,23 & 32,56 & 4,24 \\
\hline N3 & 27,394923 & 40,835019 & 31,70 & 46,09 & 22,20 & $\mathrm{~L}$ & 6,02 & 74 & 0,72 & 170,43 & 704,56 & 105,43 & 8,82 \\
\hline $\mathrm{N} 4$ & 27,395116 & 40,846442 & 48,52 & 20,53 & 30,96 & SCL & 5,98 & 92 & 3,59 & 567,14 & 2718,33 & 74,13 & 11,38 \\
\hline N5 & 27,395212 & 40,855880 & 31,70 & 37,16 & 31,13 & $\mathrm{CL}$ & 7,18 & 578 & 3,74 & 201,91 & 5453,26 & 130,82 & 13,71 \\
\hline N6 & 27,374977 & 40,824819 & 34,88 & 33,52 & 31,60 & $\mathrm{CL}$ & 6,40 & 274 & 10,20 & 443,25 & 4996,73 & 276,66 & 27,25 \\
\hline N7 & 27,374478 & 40,837882 & 38,61 & 28,57 & 32,82 & CL & 6,24 & 174 & 5,60 & 279,62 & 2134,60 & 319,46 & 21,57 \\
\hline N8 & 27,374442 & 40,846791 & 31,58 & 33,09 & 35,33 & CL & 6,00 & 138 & 3,02 & 307,93 & 4609,42 & 111,37 & 8,70 \\
\hline N9 & 27,374611 & 40,855817 & 21,70 & 43,18 & 35,12 & $\mathrm{CL}$ & 7,14 & 206 & 1,58 & 169,12 & 7527,17 & 124,82 & 1,21 \\
\hline N10 & 27,395040 & 40,865242 & 17,50 & 45,29 & 37,22 & SiCL & 7,22 & 300 & 2,44 & 250,79 & 6777,77 & 227,00 & 19,54 \\
\hline N11 & 27,394778 & 40,874049 & 11,38 & 43,20 & 45,42 & $\mathrm{SiC}$ & 7,20 & 336 & 3,02 & 150,61 & 7419,62 & 308,99 & 18,43 \\
\hline N12 & 27,374724 & 40,874108 & 12,89 & 28,98 & 58,13 & $\mathrm{C}$ & 7,34 & 258 & 1,58 & 339,24 & 8730,43 & 123,12 & 8,49 \\
\hline N13 & 27,374583 & 40,864875 & 25,86 & 36,99 & 37,15 & $\mathrm{CL}$ & 7,20 & 340 & 4,17 & 144,66 & 7932,65 & 150,79 & 11,60 \\
\hline N14 & 27,355322 & 40,864965 & 12,87 & 45,55 & 41,58 & $\mathrm{SiC}$ & 7,44 & 266 & 1,87 & 106,55 & 8520,89 & 114,72 & 3,57 \\
\hline N15 & 27,343080 & 40,874037 & 3,18 & 39,92 & 56,90 & $\mathrm{SiC}$ & 7,15 & 415 & 1,58 & 164,43 & 9880,86 & 168,68 & 14,61 \\
\hline N16 & 27,355449 & 40,873933 & 8,66 & 39,37 & 51,97 & $\mathrm{C}$ & 7,28 & 300 & 1,72 & 364,33 & 8653,97 & 224,07 & 8,73 \\
\hline N17 & 27,331448 & 40,855909 & 8,41 & 41,56 & 50,03 & $\mathrm{SiC}$ & 5,99 & 99 & 2,44 & 513,65 & 4342,05 & 226,87 & 38,82 \\
\hline N18 & 27,355353 & 40,855938 & 11,12 & 48,58 & 40,30 & $\mathrm{SiC}$ & 7,40 & 203 & 1,58 & 191,34 & 8883,94 & 106,27 & 5,09 \\
\hline N19 & 27,347020 & 40,847258 & 25,06 & 41,54 & 33,40 & $\mathrm{CL}$ & 7,15 & 245 & 2,01 & 69,72 & 8239,22 & 69,40 & 4,70 \\
\hline $\mathrm{N} 20$ & 27,355211 & 40,838200 & 33,46 & 42,24 & 24,30 & $\mathrm{~L}$ & 7,20 & 220 & 1,15 & 65,24 & 6067,42 & 74,78 & 4,57 \\
\hline $\mathrm{N} 21$ & 27,331692 & 40,838675 & 10,42 & 83,18 & 6,40 & $\mathrm{Si}$ & 7,36 & 297 & 1,29 & 350,00 & 7824,28 & 103,07 & 3,98 \\
\hline N22 & 27,331566 & 40,829214 & 18,57 & 75,01 & 6,42 & SiL & 6,65 & 270 & 2,59 & 776,97 & 3822,70 & 129,60 & 9,55 \\
\hline N23 & 27,354989 & 40,820087 & 27,77 & 35,00 & 37,23 & $\mathrm{CL}$ & 6,13 & 154 & 3,74 & 274,02 & 2337,84 & 286,49 & 17,85 \\
\hline $\mathrm{N} 24$ & 27,331685 & 40,819994 & 50,42 & 26,76 & 22,81 & SCL & 6,30 & 243 & 5,75 & 297,52 & 2469,10 & 285,71 & 34,12 \\
\hline
\end{tabular}

The lowest sand content $(3.18 \%)$ was obtained from the northern section of the research site between Oruçbeyli and Çanakçı districts and the greatest sand content $(50.42 \%)$ was obtained from high-altitude southern sections of Ganos Mountain. The greatest silt content $(83.13 \%)$ was obtained from the point between Işıklar and Semetli districts and the lowest silt content $(20.52 \%)$ was obtained from the point between Naipköy and Yeniköy districts. The greatest clay content $(58.13 \%)$ was observed around Çanakçı district and the lowest clay content $(6.40 \%)$ was obtained from the point with the greatest silt content. As it was expected, the greatest $\mathrm{pH}$ (7.44) was obtained from northern part of the research site where Naip plain is located because of transported material and the lowest $\mathrm{pH}$ (5.84) was obtained from southern part of the site close to the coast. With regard to coefficient of variation, the lowest value $(8.44 \%)$ was calculated for $\mathrm{pH}$ and the greatest value (73.51\%) was calculated for phosphorus. Akgül et al. (1995) indicated that high coefficient of variation increased error margins in interpretation of investigated parameters with classical statistics. Statistical assessments on analysis results are provided in Table 2.

Table 2. Statistical assessments on analysis results

\begin{tabular}{|c|c|c|c|c|c|c|c|c|}
\hline \multicolumn{9}{|c|}{ Descriptive Statistics } \\
\hline & Std. Deviation & Range & Minimum & Maximum & Mean & Skewness & Kurtosis & $\begin{array}{l}\text { Variation } \\
\text { coeffifiency }\end{array}$ \\
\hline$\%$ Sand & 13,35534 & 47,24 & 3,18 & 50,42 & 24,5648 & 0,31 & $-0,791$ & 54,37 \\
\hline$\%$ Silt & 13,66123 & 62,65 & 20,53 & 83,18 & 41,0265 & 1,81 & 4,313 & 33,30 \\
\hline \% Clay & 13,0846 & 51,72 & 6,4 & 58,13 & 34,4087 & $-0,284$ & 0,484 & 38,03 \\
\hline $\mathrm{ph}$ & 0,57281 & 1,6 & 5,84 & 7,44 & 6,7879 & $-0,493$ & $-1,592$ & 8,44 \\
\hline$\overline{\mathrm{EC}}$ & 110,47853 & 504 & 74 & 578 & 244,125 & 1,039 & 2,477 & 45,25 \\
\hline$\% \mathrm{OM}$ & 2,07064 & 9,48 & 0,72 & 10,2 & 2,9038 & 2,094 & 5,896 & 71,31 \\
\hline
\end{tabular}




\begin{tabular}{|l|r|r|r|r|r|r|r|r|}
\hline Magnesium (mg/l) & 177,93755 & 711,74 & 65,24 & 776,97 & 296,6839 & 1,044 & 0,941 & 59,98 \\
\hline Calcium (mg/l) & 2752,7751 & 9176,3 & 704,56 & 9880,86 & 5623,8058 & $-0,196$ & $-1,36$ & 48,95 \\
\hline Potassium (mg/l) & 86,97362 & 286,9 & 32,56 & 319,46 & 168,612 & 0,417 & $-1,217$ & 51,58 \\
\hline Phospor (mg/l) & 9,77592 & 37,61 & 1,21 & 38,82 & 13,2982 & 1,169 & 1,024 & 73,51 \\
\hline
\end{tabular}

Within the research site, clay ratio of southern sections towards the Marmora Sea was lower than the clay ratio of the northern sections towards the Naip plain. Northern sections had quite high clay ratios. Muhacir formation of upper Oligocene-aged northern sections of the research site are mostly composed of clay deposits (Boyraz 1998). After all, Naip plain has been used to excavate clay for brick industry for years (Özşahin et al. 2018). On the other hand, northern sections of Ganos Mountain, the section towards the Marmora Sea, have greater sand contents because of the parent material. Greater $\mathrm{pH}$ levels of the sections with greater calcium levels in calcium and $\mathrm{pH}$ maps indicated that the maps were generated correctly. Laminated schists of the region are composed of dolomitic and thin limestone layers of marine deposits (Boyraz 1998). Thus, the sections of Naip plain towards the Marmora Sea had greater lime contents. Just because of these lime Stones, northern sections had greater calcium contents. Just because of high lime contents of northern sections of Ganos Mountain, $\mathrm{pH}$ levels were greater than the southern sections. Lower lime levels of southern sections were also attributed to parent material of forest cover of these sections. The maps generated with the aid of Inverse Distance Weighting (IDW) method for soil properties are presented in Fig. 2.

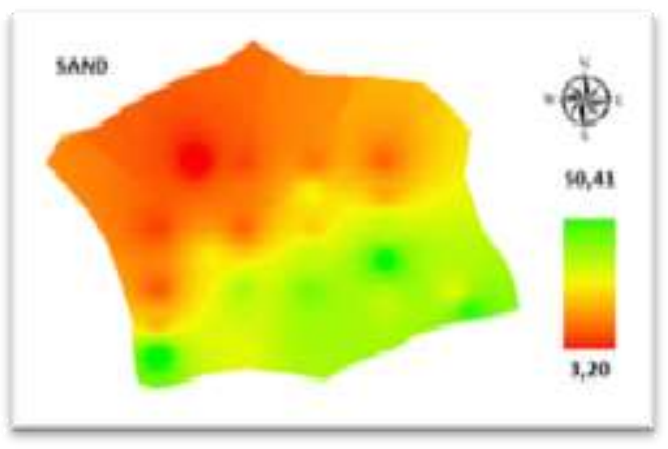

Fig.2.a.

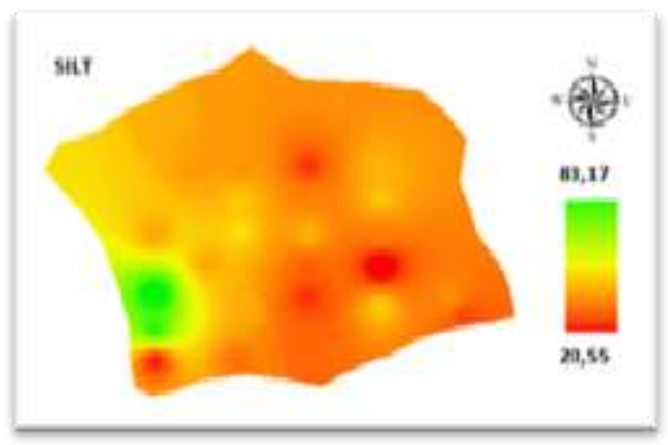

Fig.2.c.

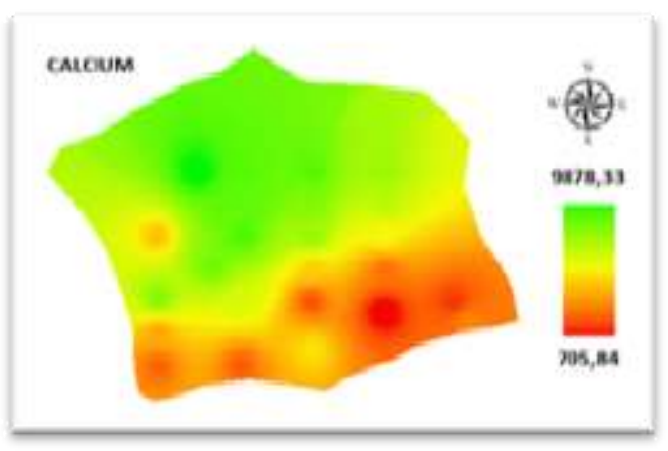

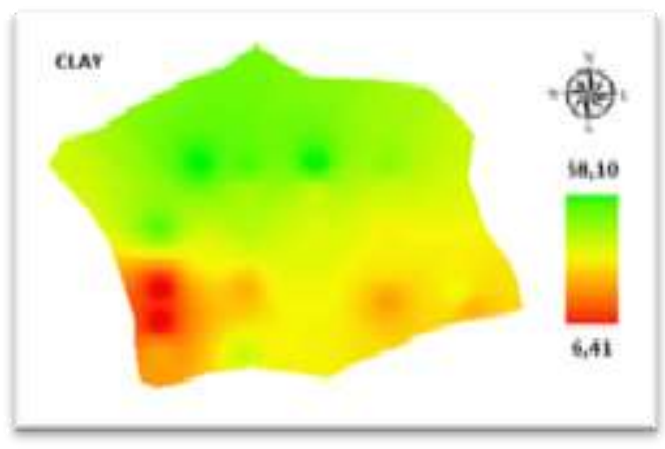

Fig.2.b.

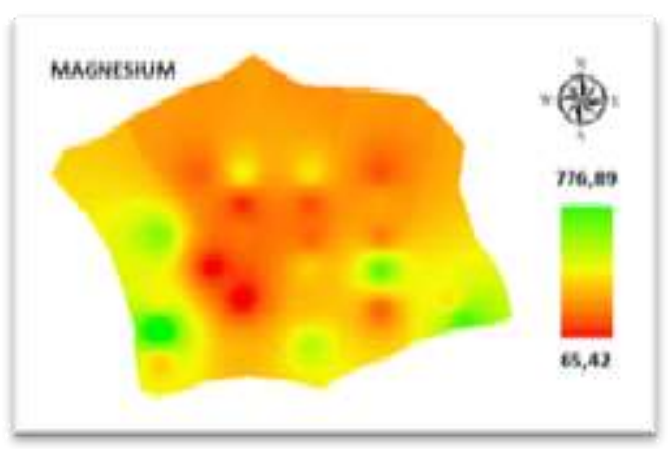

Fig.2.d.

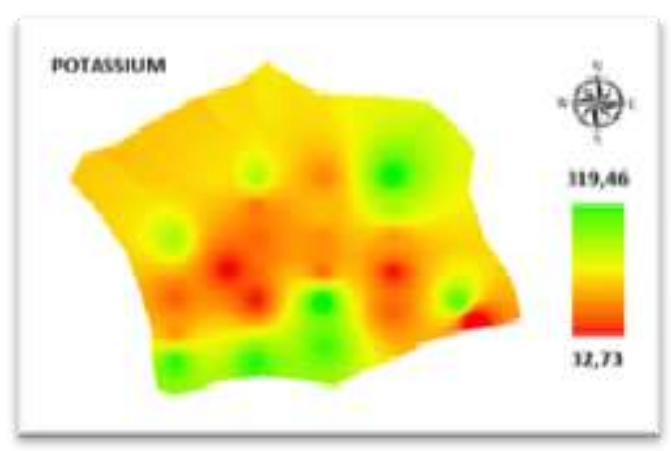


Fig.2.e.

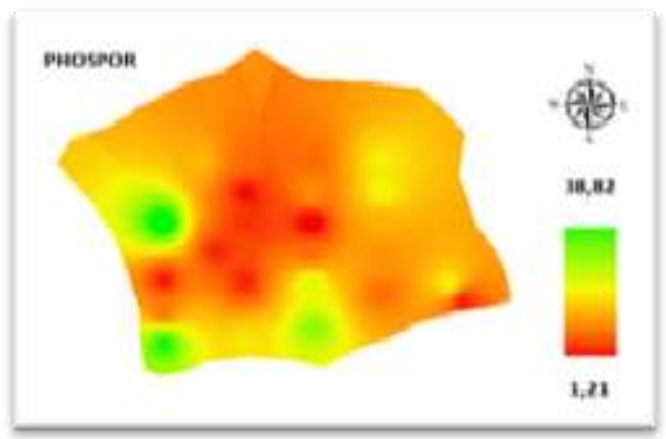

Fig.2.g.

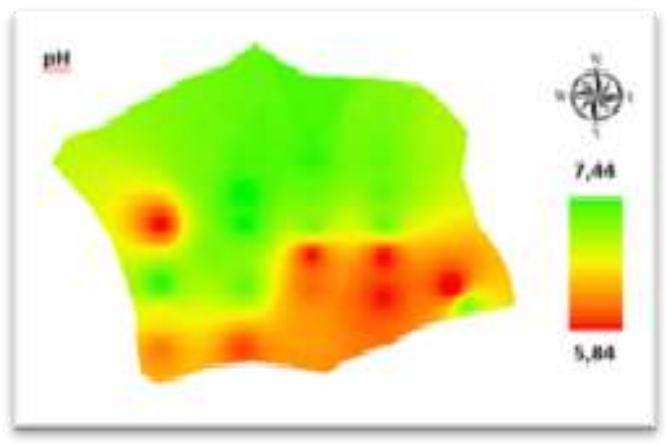

Fig.2.i.
Fig.2.f.

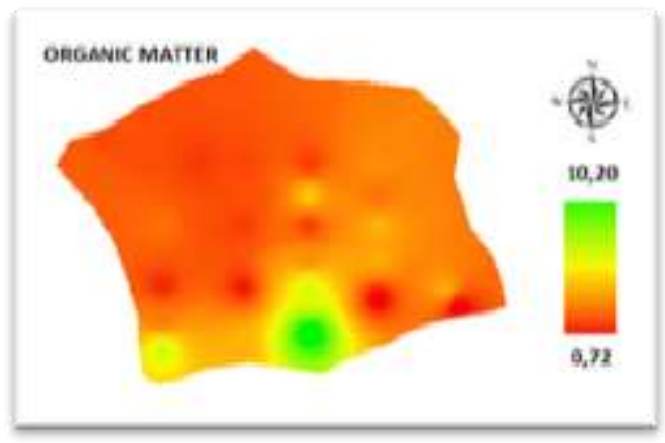

Fig.2.h.

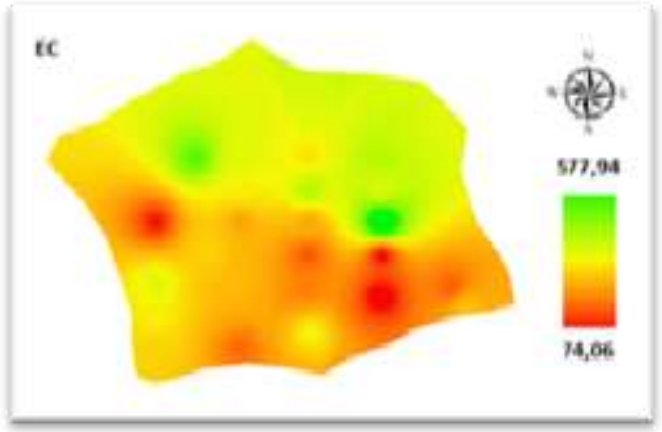

Fig.2.j.

\section{Fig. 2. Maps of soil properties generated through IDW method}

Because of sloped terrain, the research site is exposed to severe erosion. Besides, previous forest cover over the sections towards the Naip plain has already been replaced by idle vineyards. Parent material reached to surface from place to place and such a case resulted in differences in $\mathrm{Mg}, \mathrm{K}$ and $\mathrm{P}$ contents, mostly related to parent material in some sections of the research site. Severe erosions created water conduits over the southern slopes of Ganos Mountain and eroded material then flows into the dam constructed in Naip district on the south of Ganos Mountain. Over the section with the greatest organic matter content, there is a delta towards the Marmora Sea. The delta around Ayvasıl district is mostly composed of transported material, thus has an organic matter content of about $10 \%$. The $\mathrm{pH}$ level of that section was then at low levels.

\section{Conclusion}

Present findings revealed that spatial distribution of soil physical and chemical characteristics of the research site could be investigated. Sampling procedure plays a great role in identification of soil properties. Besides number of sampling points, homogeneous sampling is also a significant issue in such studies. However, it is quite hard to manage such a homogeneous sampling in practice. In other words, non-homogeneous samplings may not reveal accurate information about soil properties. Since soils exhibit continuous variations, interpolation methods can be used to estimate the values of non-sampled points. Spatial distribution maps generated through estimated data may reveal a general information about the soil properties and have great contributions to a database to be generated. Determination of soil nutrients may aid in fertilization and nutrition practices. Texture maps provide significant contributions to erosion works to be implemented.

It was observed in present study that clay and silt contents were at quite high levels over the northern sections of Ganos Mountain towards the Naip plain just because of transported material. Again because of lime layers of these transported material, calcium and accordingly $\mathrm{pH}$ levels of these sections were also high. Effects of parent material were dominant over the sections towards the Marmora Sea. Since the parent material is composed of sand stones, sand content was high and $\mathrm{pH}$ levels were low over these sections. Calcium content was also low in sections towards the Marmora Sea. Organic matter content of the sections around Naip plain was low because of erosion and anthropogenic activities, but greater in sections towards the Marmora Sea. Organic matter content was quite high especially over the upper sections of the delta 
around Ayvasil district. Magnesium, potassium and phosphorus contents were low in sections around Naip plain because intense land use for agricultural purposes, but variations were observed based on intensity of land use. Considering the sloppy terrain and erosion cases of the research site, present maps help in finding solutions for rapid fill up of newly constructed Naip dam with transported material. Present findings on soil nutrients may also contribute to farmers in reducing labor, time and costs of agricultural practices.

\section{References}

[1] Akgül M, Öztas T, Canbolat MY (1995) Determination of Textural Variations in Soils of Ataturk University wşth Geostatistical Methods. Akalın Soil and Environment Symposium. I: 82-91, Ankara. (in Turkish).

[2] Anonymous (2009) ArcGIS Geostatistical Analyst, İşlem Gographical Information Systems Engineering and Education Co. p:13 -2009.

[3] Anonymous (1993) Soil Survey Laboratory Methods and Procedures For Collecting Soil Samples. Soil Survey Investigation Report No:1 USDA. Washington DC., USA.

[4] Anselin L (2002) Under the Hood Issues in the Specification and Interpretation of Spatial Regression Models. Agricultural Economics, 27: p. 247-267.

[5] Anselin, L (2009) 30 years of Spatial Econometrics. Regional Science, 89(1): p. 3-25.

[6] Anselin, L, Amaral PV, Arribas D (2012). Technical Aspects of Implementing GMM Estimation of the Spatial Error Model in PySAL and GeoDaSpace.

[7] Başbozkurt H, Öztaş T, Karaibrahimoğlu A, Gündoğan R, Genç A (2013). Determination of Spatial Variation Patterns of Soil Properties with Geostatistical Methods. Journal of Agricultural Faculty of Atatürk University. 44 (2) : 169-181 (in Turkish).

[8] Bouyoucos G J (1953) An improved type of soil hydrometer. Soil Sci

[9] Boyraz D (1998) Classification, Mapping and Land Use Planning for Soils of Işıklar Plain (Tekirdağ) Based on Soil Taxanomy. Graduate Thesis, Trakya University Institute of Natural and Applied Sciences. p:15 (in Turkish).

[10] Cao S, Lu A, Wang J, Huo L (2017) Modeling and mapping of cadmium in soils based on qualitative and quantitative auxiliary variables in a cadmium contaminated area. Science of the Total Environment, 580: 430-439.

[11] Denton OA, Aduramigba-Modupe, VO, Ojo AO, Adeoyolanu OD, Are, KS, Adelana AO, Oke AO (2017) Assessment of spatial variability and mapping of soil properties for sustainable agricultural production using geographic information system techniques (GIS). Cogent Food and Agriculture, 3(1): 1-12.

[12] Erdem H, Budak M, Acir N, Gökmen F (2012) Micronutrient variability in a lacustrine environment of calcic haplosalids. Fresenius Environmental Bulletin, 21(3): 553-562.

[13] Glendell M, Granger SJ, Bol R, Brazier RE (2014) Quantifying the spatial variability of soil physical and chemical properties in relation to mitigation of diffuse water pollution. Geoderma, 214: $25-41$.

[14] Goovaerts P (1998) Geostatistical tools for characterizing the spatial variability of

[15] Günal, H., Acir, N., Budak, M., 2012. Heavy metal variability of a native saline pasture in arid regions of Central Anatolia. Carpathian Journal of Earth and Environmental Sciences, 7(2): 183193.

[16] Jackson ML (1958) Soil Chemical Analysis. Prentice Hail Inc. Englewood Cliffs,N.J. microbiological and physico-chemical soil properties. Biology and Fertility of Soils, 27(4): 315334.

[17] Özşahin E (2015) Geomorphological Characteristics of Marmara Sea Akaçlama Basin (Tekirdağ) between Şarköy Stream (Şarköy) and Bağlar Stream (Marmara Ereğlisi). Journal of Academic Social Researches. 10: 360-393 (in Turkish).

[18] Özşahin E, Sarı H, Eroğlu İ (2018) Environmental Impacts of Spatial and Temporal Variations of Stone Quarries in Naip plain and close surroundings (Tekirdağ). Yüzüncüyıl University Journal of Agricultural Sciences. 28 (3): 331-344 (in Turkish).

[19] Öztas T (1995) Significance and Implementation of Geostatistics in Soil Science. İ. Akalın Soil and Environment Symposium. I:271- 280, Ankara (in Turkish). 
[20] Richards LA (1954) Diagnosis and Improvement of Saline and Alkali Soils. USDA.Handbook, No:60. USA.

[21] Sabeti H, Moradzadeh A, Ardejani FD, Azevedo L, Soares A, Pereira P, Nunes R (2017) Geostatistical seismic inversion for non-stationary patterns using direct sequential simulation and co-simulation. Geophysical Prospecting, 65(1): 25-48.

[22] Sağlam MT (2008) Soil and Water Chamical Analysis Methods. Trakya University Agricultural Faculty, Publication No: 189. Supplementary Course Material No: 5. Tekirdağ (in Turkish).

[23] Turgut B, Öztaş T (2012) Determination of Spatial Variations in Some Soil Characteristics with Geostatistical Methods. Süleyman Demirel University Journal of Agricultural Faculty, 7(2): p. 1022 (in Turkish).

[24] Vasu D, Singh S.K, Sahu N, Tiwary P, Chandran P, Duraisami VP, Ramamurthy V, Lalitha M, Kalaiselvi B (2017) Assessment of spatial variability of soil properties using geospatial techniques for farm level nutrient management. Soil and Tillage Research, 169: 25-34.

[25] Webster R, Oliver MA (2007) Geostatistics for Environmental Scientisits. Second Edition. John Wiley and Sons Limited, Chichester, England. 